\title{
WHAT DO UNIVERSITY ENDOWMENT MANAGERS WORRY ABOUT? AN ANALYSIS OF ALTERNATIVE ASSET INVESTMENTS AND BACKGROUND INCOME
}

\author{
Harvey S. Rosen \\ Alexander J. W. Sappington \\ Working Paper 21271 \\ http://www.nber.org/papers/w21271 \\ NATIONAL BUREAU OF ECONOMIC RESEARCH \\ 1050 Massachusetts Avenue \\ Cambridge, MA 02138 \\ June 2015
}

We are grateful to Ken Redd of the National Association of College and University Business Officers for providing us with university endowment data, to Nemanja Antic, Will Dobbie, Stephen Dimmock, Henry Farber, Andrew Golden, Peter Perdue, Ulrich Mueller, and two referees for many helpful suggestions, and to Oscar Torres-Reyna for his generous assistance with coding issues. Financial support from Princeton's Griswold Center for Economic Policy Studies is gratefully acknowledged. The views expressed herein are those of the authors and do not necessarily reflect the views of the National Bureau of Economic Research.

NBER working papers are circulated for discussion and comment purposes. They have not been peerreviewed or been subject to the review by the NBER Board of Directors that accompanies official NBER publications.

(C) 2015 by Harvey S. Rosen and Alexander J. W. Sappington. All rights reserved. Short sections of text, not to exceed two paragraphs, may be quoted without explicit permission provided that full credit, including (C) notice, is given to the source. 
What Do University Endowment Managers Worry About? An Analysis of Alternative Asset Investments and Background Income

Harvey S. Rosen and Alexander J. W. Sappington

NBER Working Paper No. 21271

June 2015

JEL No. I22,I23

\section{ABSTRACT}

This paper examines whether university endowment managers think only in terms of the assets they manage, or also take into account background income, the other flows of income to the university. Specifically, we test whether the level and variability of a university's background income (e.g., from tuition and government grants) affect its endowment's allocations to so-called alternative assets such as hedge funds, private equity, and venture capital. We find that both the probability of investing in alternative assets and the proportion of the portfolio invested in such assets increase with expected background income and decrease with its variability.

Harvey S. Rosen

Department of Economics

Fisher Hall

Princeton University

Princeton, NJ 08544-1021

and NBER

HSR@princeton.edu

Alexander J. W. Sappington

4545 SW 97th Terrace

Gainesville, FL 32608

alexandersappington@gmail.com 


\section{Introduction}

The management of university endowments has been the focus of increased attention in recent years. As high-profile endowment portfolios outperformed the market year after year during the 1990s and much of the 2000s, private investors and academics alike sought to understand the reasons behind their success. One of the primary causes, it appears, was increased investment in risky and illiquid assets, including so-called alternative assets such as hedge funds, private equity, and venture capital. However, the Great Recession of 2008 changed public perceptions of this approach. Endowments across the country suffered heavy losses. In one particularly dramatic case, Antioch College nearly had to shut down in 2008 due to financial distress (Lerner, 2008). Newspaper reports berated endowment managers who "took the plunge" into alternative investments (Stewart, 2013), arguing that their reckless decisions had caused universities to raise tuition, freeze campus construction projects, and lay off staff. Many commentators concluded that endowment managers had gone the way of Wall Street by taking on excessive risk and failing to provide adequate financial support to their universities against negative revenue shocks. At the same time, universities that limited their investment in alternative assets were praised for their prudence. ${ }^{1}$

This brief history raises at least two important questions. First, there has been substantial heterogeneity both across universities and over time in the share of endowments invested in alternative assets. What factors underlie universities' asset allocation decisions? Second, are endowments supporting their universities in times of financial distress, or are they serving some

\footnotetext{
For example, Humphreys et al. (2010) note approvingly that Boston College invested only a small portion of its endowment in alternative assets, unlike other northeastern schools such as Harvard University.
} 
other purpose such as stockpiling funds to enhance university prestige? We find that by addressing the first question, we are able to shed some light on the second.

An issue of particular importance in this context is the extent to which the flows of university income from non-endowment sources such as tuition, private donations, and public funding affect portfolio decisions. Such nonfinancial flows are referred to as "background income." A substantial theoretical literature on household portfolio decision-making has shown that uncertainty with respect to background income such as wages should affect asset allocation decisions (See, for example, Merton (1971).) In the same way, Merton (1992) and others have demonstrated that, under reasonable conditions, endowment managers' optimal portfolio decisions will depend upon both the expected value and standard deviation of background income, inter alia. Specifically, Merton's (1992) model predicts that, like households, institutions that face substantial risk in their flows of background income will choose to reduce their exposure to financial risk, other things being the same. ${ }^{2}$

A model of household portfolio behavior might not be entirely relevant to universities for many reasons, but one deserving special attention is that the individuals who make endowment decisions do not necessarily take into account the overall economic environment of the university. While the assumption that a single individual considers her complete financial situation when making personal portfolio decisions seems plausible, it is not as clear that endowment managers are fully informed about the university's background income, despite the fact that university executives and trustees ultimately have legal control over portfolio decisions. Even if endowment managers have the requisite information, there is a potential agency

2 An intriguing implication of Merton's model is that universities whose donations are disproportionately from one sector of the economy might hedge against variability in these donations by reducing the exposure of their endowment portfolios to that sector. Thus, for example, a university like Stanford that receives substantial contributions from Silicon Valley might hold very few technology stocks (or perhaps even short them). 
problem - it might not be in their self-interest to use the information to advance the interests of the institution as a whole (Gilbert and Hrdlicka (2013)).

In this paper we investigate whether universities' asset allocations do in fact incorporate information about fluctuations in background income. We examine both the decision whether or not to hold alternative assets (the extensive margin) and the proportion of the portfolio held in such assets (the intensive margin). Our results contribute to the growing empirical literature on universities' portfolio decisions, and also shed light on one of the major is sues in the economics of higher education, the role played by university endowments. Our main finding is that expectations regarding background income play an important role in endowment managers' decisions. Although we cannot exclude other possible objectives that endowment managers might have, managers do appear to incorporate forecasts of the expected level of background income and its variability into their portfolio allocation decisions. More precisely, universities that expect higher levels of background income: (i) are more likely to invest in alternative assets; and (ii) allocate a larger percentage of their endowments to alternative assets. According to our estimates, the likelihood that a university decides to include alternative assets in its portfolio in a given year increases by 11.3 percentage points with a one standard deviation increase in expected background income, and decreases by 8.2 percentage points with a one standard deviation increase in the variability of background income ("background risk"). In addition, the share of a university's portfolio held in alternative assets increases by 7.5 percentage points and decreases by 1.1 percentage points with a one standard deviation increase in expected background income and background risk, respectively. We also document considerable heterogeneity across types of universities in the response of asset allocation decisions to the expected value and variability of background income. Specifically, the asset allocation decisions 
of public universities, universities not primarily focused on research, and universities with large endowments are all particularly responsive to changes in the mean and variability of background income.

Section 2 reviews the pertinent literature, with an emphasis on the predictions of economic theory about how endowment decisions depend on background income. In Section 3 we describe the data and present some summary statistics. Section 4 details the empirical methodology, including how the moments of background income are calculated. Section 5 presents the findings and assesses their robustness. We conclude in Section 6 with a summary and suggestions for future research.

\section{Literature Review}

The purpose of endowments. Many universities maintain large endowments, but the reason for their existence is not obvious. Companies that accumulate large amounts of cash are sometimes viewed as weak because such behavior might suggest an absence of profitable investment opportunities. Why, then, is a large endowment viewed as a sign of a university's strength and prestige? Hansmann (1990) argues that universities create endowment funds to preserve reputational capital, to ensure intellectual freedom, and to protect against financial shocks. ${ }^{3}$ He notes, however, that there is not strong support for any of these explanations, and indeed, a leitmotif in the recent literature is that this rather benign view of the role of endowments is at variance with reality. Goetzmann and Oster (2012) posit that, whatever the original reason for creating endowments, the size and performance of a university's endowment

3 He further observes that universities can be more affected by financial downturns than corporations because: (i) universities cannot is sue equity; (ii) it is relatively difficult for universities to take on debt (since their assets are organization-specific and serve as poor collateral); and (iii) costs for universities are largely fixed in the shortrun due to the tenure system for faculty and the fact that the number of students cannot be immediately reduced. 
has now become so associated with its prestige that universities pursue strategies that are designed solely to maximize the endowment's return. ${ }^{4}$ This notion is supported by Brown et al. (2014), whose econometric analysis of payouts from endowments indic ates that universities reduce spending more in response to negative shocks than they increase spending in response to positive shocks. They call such behavior "endowment hoarding," because it is consistent with the notion that university leaders and endowment managers seek to amass wealth for purposes beyond support of university operations, perhaps because they believe their future employment opportunities or compensation are functions of endowment size. The idea that endowments might be larger than optimal is buttressed by the theoretical work of Gilbert and Hrdlicka (2013), who model the size and composition of a university's endowment as the outcome of a decision making process that balances the objectives of self-interested stakeholders (say, those faculty members who are interested only in their own salaries) and altruistic stakeholders, who want the university to use its resources to undertake productive external projects. They show that the equilibrium outcome in such a situation is for a university to have a risky and large endowment. In a sense, this formalizes Hannsman's (1990) observation that agency issues may lead universities to select financial policies, including asset allocations, that "serve the personal interests of a university's faculty and administrators."

The "endowment model" of investing. One reason for the relatively limited literature on endowments is that, prior to the mid-1980s, they were of little interest to financial experts and researchers. Historically, endowments had adopted conservative investment strategies, largely investing in bonds and high-dividend stocks. The late 1960s saw endowment funds begin to shift to riskier stocks and fewer bonds, but the stock market downturn of the 1970s abruptly ended

4 Although the U.S. News and World Report ranking formu la does not include endowment size per se, financial resources per student is an important factor, meaning that schools with large endowments tend to receive higher ranks, ceteris paribus (Morse, 2012). 
that trend. In 1985, David Swensen and Dean Takahashi of Yale University developed the "endowment model," which dictates investing only a small amount in traditional choices like U.S. equities and bonds, and devoting a more significant portion of the portfolio to a class of non-traditional assets known as alternative as sets (Swensen, 2009). These include hedge funds, private equity funds, venture capital funds, oil and gas, and commodities. As shown by Kaplan and Schoar (2005) and others, such assets are considerably more risky than traditional U.S. equity investments.

Importantly, as well as being risky, alternative assets are relatively illiquid. Hedge funds, private equity, and venture capital all tend to have long lock-up periods (Lerner, Schoar and Wang 2008; Brown et al., 2008). The central idea behind the endowment model is that liquidity should not be a primary concern for endowments. Unlike individuals, institutional investors like universities have very long time horizons, and so liquidity, which comes at a high price in the form of lower returns, is not essential. ${ }^{5}$ Despite the risks associated with alternative assets, their upside potential has made them very popular among many universities. As noted below, in our sample, about 90 percent of university endowments held alternative assets in 2009, and conditional on holding alternative assets, the mean proportion in the portfolio was 30 percent. Portfolio allocation. A substantial theoretical literature examines how household investment decisions deviate from the predictions of classical portfolio theory in the presence of background income. In settings where all income is derived from invested wealth, standard portfolio theory characterizes optimal investment strategies as a balance between the risk and return of the various asset classes. In practice, though, a household's total income typically consists of both financial portfolio returns and background income such as wages. Like financial income, background income has a return (the expected value of the per-period income flow) and

\footnotetext{
5 Pension funds presumably face a similar situation.
} 
a risk (the variability in the income flow). It is thus reasonable to think of back ground income as another investment class in a more comprehensive portfolio. Because background income entails a non-tradable risk and return, optimal investment policy typically would dictate changes in other portfolio investments when background income is added to the portfolio. Merton (1971) shows that under certain reasonable conditions, there is a positive "mean effect" of background income - optimal portfolio riskiness increases with expected background income. Kimball (1993) and Gollier and Pratt (1996) demons trate a negative "variability effect" under similar assumptions, showing that increased background risk leads to reduced portfolio risk.

The empirical literature on household portfolio choice, including Guiso et al. (1996) and Vissing-Jorgensen (2002), suggests that observed behavior is consistent with Merton's (1971) basic model. In particular, when expected background income declines or background risk increases, households reduce their holdings of relatively risky assets, holding other factors constant.

Because of the long-standing debate over the purpose of endowments noted above, the likely impact of background risk on university endowment decisions is not clear. Endowment managers will consider background risk only to the extent that the endowment's role is to hedge against revenue shocks (Merton 1992)). If, alternatively, as Tobin(1974) suggests, the endowment's purpose is to generate a stable yearly payout in order to ensure intergenerational fairness, then the university's background income will have little effect on endowment portfolio decisions. Similarly, if endowment managers simply try to maximize portfolio returns, background income will not come into play when determining how to invest endowment as sets. In addition, regard less of the intended purposes of endowments, agency issues may be a factor. As Dimmock (2012) notes, if managers tend to be rewarded for generating high returns rather 
than for properly hedging risks, they may choose portfolio allocations that are unresponsive to background income flows.

In addition to risk, the illiquidity of alternative assets may play a role in the determination of asset selection and allocation. ${ }^{6}$ If endow ments are used to smooth income during times of financial stress, universities that are more likely to experience severe financial conditions - those whose expected background income is relatively low and at the same time relatively highly variable - will be more adversely affected by illiquidity and tend to shift away from alternative assets. Thus, the illiquidity of alternative as sets reinforces the positive mean effect and negative variability effect of background income.

To our knowledge, Dimmock (2012) has provided the only econometric investigation of the relationship between background income and university endowment decisions. ${ }^{7}$ This important paper examines the impact that the variability of background income had on endowment asset allocation in the 2002-2003 academic year. ${ }^{8}$ One key finding is that, indeed, higher background risk reduces the fraction of the portfolio allocated to alternative assets, other things being the same.

Our work has the same general goal as Dimmock's (2012) analysis, but complements it in at least three important respects. First, we estimate our model of the share of the portfolio invested in alternative assets with panel data, which allows us to include time and entity fixed effects. The inclusion of time effects reduces the likelihood that the results are idiosyncratic to

6 Arrondel et al. (2010) demonstrate that household portfolio investments are affected by the expected probability that the hous ehold will beco me liquidity constrained.

7 Several other studies, including Brown et al. (2010) and Goetzmann and Oster (2012), examine a variety of determinants of endowment investment behavior, but do not consider the role of background income.

8 Like Dimmock (2012), our data on portfolio allocations are provided by the National Association of College and University Business Officers (NACUBO). His version of the NACUBO data did not allow one to link the investment allocations of individual endowments to specific universities prior to 1995. The more recent NACUBO data set that we employ allows us to draw thes e links. Consequently, we have access to both earlier and more recent data than Dimmock. 
some particular year. The entity effects control for all time-invariant differences across universities, including those associated with unobservable variables. In the context of Gilbert and Hrdlicka's (2013) model of endowment portfolio allocation, one important example of such a fixed effect is the intensity of the non-altruistic stakeholders' preferences for benefits that do not promote the interests of the institution as a whole. Second, the only attribute of background income included in Dimmock's model is its riskiness. Following the theoretical models discussed above as well as Vissing-Jorgensen's (2002) empirical analysis of household portfolios, we take into account the expected value of background income as well. Third, while Dimmock (2012) focuses on how background risk affects the proportion of the endowment allocated to each asset class, we extend his analysis to include the decision of whether to participate in alternative assets at all.

\section{Data}

Our data come from two sources, the Integrated Postsecondary Education Data System (IPEDS) and the National Association of College and University Business Officers (NACUBO). IPEDS provides data on university finances, such as flows of tuition, government grants, and alumni gifts, as well as fixed university characteristics like university type (for example, public or private) and geographic location. The National Center for Education Statistics asks schools to submit this information on an annual basis. For most variables, the dataset extends from 1983 to 2009. The information from IPEDS is publicly available. ${ }^{9}$

The NACUBO dataset supplements the IPEDS data with yearly information on the value of each university's endowment, the allocation of the endowment among the primary asset classes, and the endowment's annual return (net of fees). When NACUBO began the survey in

\footnotetext{
${ }^{9}$ Our IPEDS analysis sample is available upon request.
} 
1987, 275 schools accepted its invitation to participate. By 2009, the dataset included 729

schools. Universities that submit their data receive privileged access to the results of the survey. One reason to participate is to learn about endowment practices at other institutions. While the data are not publicly available, NACUBO grants access to researchers with bona fide proposals. The NACUBO data have been used in several other studies, including Brown et al. (2014) and Dimmock (2012).

Combining the two datasets gives us annual observations for 729 four-year institutions between 1987 and 2009. Of these, 213 are public universities and 516 are private. These schools comprise approximately one-third of all four-year institutions. Given that the NACUBO survey is voluntary, these schools are not perfectly representative of all four-year institutions. ${ }^{10}$ Still, the NACUBO dataset is an invaluable source of information on the investment behavior of an important segment of US higher education.

The data do not provide complete information for every university for every year between 1987 and 2009. On average, data are reported for a university in only 13 of the 23 years. This is due primarily to the fact that the number of schools responding to the NACUBO survey has been growing over time. Once a university reports its endowment data to NACUBO, it typically does so consistently in all subsequent years. In contrast, the number of institutions in the IPEDS dataset barely varies from year to year.

In order to avoid undue influence by outliers, we dropped observations with a mean or standard deviation of background income in the top or bottom one percent. ${ }^{11}$ This left us with an

10 Schools in the NACUBO sample are more likely to be private and have larger student populations than those in the IPEDS data. See Lau and Rosen (2014).

11 In some cases, background income for an institution increased or decreased by extraordinary amounts in a short period of time. The Chronicle of Higher Education (2013) reports large private gifts that, in some cases, induced increases in background income of more than 1000 percent in a single year. Also, in a few cases, the proportions 
analysis sample consisting of 10,049 observations on 709 universities. Summary statistics are provided in Table 1. ${ }^{12}$ The first bank of figures shows the proportion of the universities that are private and the kinds of degrees they offer. Previous work indicates that such variables are generally significant correlates of various kinds of financial behavior. ${ }^{13}$ Next are background income and its primary components: tuition, public funding, and private giving. (All dollar figures are converted to 2009 dollars using the consumer price index.) The large difference between the mean (\$358 million) and median (\$111 million) reflects the well-known fact that resources across universities are highly unequal (Desrochers and Wellman, 2011).

The last set of statistics shows total endowments and their allocation across asset classes. The average endowment size, $\$ 515$ million, masks considerable heterogeneity across institutions: it is almost three times the median of $\$ 179$ million. The value of endowments has varied across time as well. During the economic boom of the 1990s, endowments increased in value rapidly the average value in the NACUBO data increased by $\$ 202$ million dollars (in 2009 dollars) between 1993 and 2000. That decade of growth ended abruptly with the collapse of the dot-com bubble in 2001. Endowments subsequently increased as the economy improved until the onset of the Great Recession of 2008, after which time endowment values fell by about 30 percent. Note, however, that these trends must be interpreted cautiously because, as noted above, the composition of the NACUBO sample has been changing over time.

of the various assets reported by NACUBO summed to less than 95 percent or more than 105 percent. To mitigate reporting error, we dropped these observations as well.

12 As noted above, the number of years that universities appear in the analysis sample varies across universities. The figures in the first panel of Table 1 do not weight by the number of observations; the rest of the figures do.

13 See, for example, Lerner et al. (2008). 
The table indicates that alternative assets comprise about 17 percent of university endowments in our analysis sample. ${ }^{14}$ This figure is the mean over all institutions; if we take the mean conditional on having a positive amount invested in alternative assets, the share is 20 percent. In 1987, the beginning of our sample period, the unconditional mean share of alternative assets was 5 percent, and only 62 percent of the endowments held any alternative assets. By the end of our sample period, the unconditional proportion was 30 percent, and 90 percent of the institutions held alternative assets. In our data, a university makes a transition from holding alternative assets to not holding them in only 2.5 percent of our observations (universitypair years). That is, once an endowment includes alternative assets in its portfolio it hardly ever reverses that decision, an observation that has important implications for our econometric strategy.

\section{Empirical Methodology}

In this section we develop a framework for testing whether a university endowment manager's demand for alternative assets increases with expected background income and decreases with its variability, other things being the same. Of course, endowment managers' expectations of future background income and their beliefs about its variability are not observable to the econometrician; they need to be constructed. In her analysis of household portfolio decisions, Vissing-Jorgensen (2002) suggests a two-step procedure to deal with this issue: First, construct for each agent in each year the expected value of background income and

14 Some alternative assets are illiquid, an observation that leads to the question of how they are valued. NACUBO provides no guidelines to institutions with respect to valuation procedures, and receives no information about the procedures employed. According to our conversations with one endowment specialist, the manager of each alternative investment is generally asked by the head of the overall endowment to provide assessments of the value of the assets under his or her management. There are common indus try practices for how the valuation is done. For example, venture capital is typically valued at the price paid in the last financing round or some lower value reflecting deteriorating business conditions. For real assets, standard apprais al techniques are used. 
its variability; and second, use these as regressors in an equation explaining decisions about investing in risky assets. We adopt this general strategy, and now discuss each step in turn.

Expected background income and its variability. Vissing-Jorgensen's approach assumes that the log of background income follows a simple autoregressive process. If the only relevant information available to portfolio decision makers in a given year is past values of background income, then estimates of the parameters of this process allow one to estimate expected background income and its variability. Formally, assuming that the observational units are universities, the forecasting equation is:

$$
\ln Y_{i t}=\alpha+\beta \ln Y_{i, t-1}+\varepsilon_{i t}
$$

where $Y_{i t}$ is realbackground income for university $i$ in year $\mathrm{t}, \alpha$ and $\beta$ are parameters, and $\varepsilon_{i t}$ is a normally distributed and uncorrelated error term. If we let $\mathrm{M}_{i t}$ denote the expected value of the $\log$ of university $i$ 's background income in period $t$, it follows that $\mathrm{M}_{i t}=\alpha+\beta \ln Y_{i, t-1}$. The conditional second moment of the log of background income, denoted $v_{i t}$, is $\operatorname{Var}\left(\ln Y_{i t} \mid \ln Y_{i, t-1}\right)$, which is the square of the standard deviation of the residuals over the time period used to estimate the model. With $\mathrm{M}_{i t}$ and $v_{i t}$ in hand, one can compute the expected value $\left(\mu_{i t}\right)$ and standard deviation $\left(\sigma_{i t}\right)$ of the level of background income as

$$
\begin{gathered}
\mu_{i t}=E\left(Y_{i t} \mid Y_{i, t-1}\right)=e^{\mathrm{M}_{i t}+\frac{v_{i t}}{2}} \\
\sigma_{i t}=\sqrt{\operatorname{Var}\left(Y_{i t} \mid Y_{i, t-1}\right)}=\sqrt{e^{\left(2 \mathrm{M}_{i t}+v_{i t}\right)}\left(e^{v_{i t}}-1\right)}
\end{gathered}
$$

The variables $\mu_{i t}$ and $\sigma_{i t}$ are then the empirical counterparts of the expected value of background income and its variability, respectively. ${ }^{15}$

\footnotetext{
15 The estimated values of $\mu_{i t}$ and $\sigma_{i t}$ do not exhibit any discernib le patterns over time.
} 
Note that the parameters of the forecasting equation (1) do not vary by institution. That is, the model constrains every school to have the same process for generating background income. This formulation has the virtue of simplicity, but it is not hard to imagine that the processes generating background income vary across institutions. A different tactic would be to estimate the equation separately for each institution. However, we do not have enough observations for each school to obtain meaningful estimates. As a compromise, we also estimated equation (1) separately for various subsamples of our data. With this setup, the background income generating process is the same for all institutions of a given type (say, public or private), but can differ across types. As reported below, while our results are qualitatively similar across different types of institutions, both statistical significance and point estimates do differ.

A related question is how many years of data should be used to estimate equation (1). In this context, we assume that the only data available to the endowment managers are the total inflation-adjusted dollar amounts of background income for all years up to but not including the year portfolio decisions are made. ${ }^{16}$ We also assume that endowment managers give primary consideration to background income in relatively recent years when making their decisions. Specifically, we assume that endowment managers only consider background income data from a specified window of years prior to the year in which they make their portfolio decision. The selection of a window length involves a tradeoff: a window that is too short will not provide sufficient observations to generate meaningful parameter estimates; a window that is too long will result in estimates based on information that endowment managers probably do not consider very relevant to their current decision making problem. Theory provides no guidance here. We

16 Conceivably, universities could provide their endowment managers with some contemporaneous information to help inform their investment decisions. However, without information on the precise timing of the portfolio decisions, we cannot know whether this is a realistic possibility. 
experimented with various window lengths, and found that the best fit to the first stage equation was obtained when we used data from six years prior to the year in question for estimation. Therefore, we estimate equation (1) with data from years $t-7$ to $t-1$, and calculate the standard deviation of the residuals from the estimated model over the same period. ${ }^{17}$ As noted below, we also experimented with windows of 5 and 7 years and found quite similar results.

The portfolio share of alternative assets. Standard theoretical considerations suggest that in addition to the first two moments of the background income generating process, a model of portfolio selection needs to take into account other variables that might affect the decisionmaker's utility function. Thus, for example, in her analysis of household demand for risky assets, Vissing-Jorgensen (2002) includes variables such as education and race. In the same spirit, Dimmock's (2012) model of university portfolio allocation includes an indicator for whether the school is public or private and measures of its selectivity, among other variables. The panel nature of our data allows us to estimate a fixed effects model, and hence take into account all university characteristics that do not change over time. We also include time effects to control for factors that likely affect all institutions' decisions in a given year, such as the macroeconomic environment, the performance of the stock market, and so on. Thus, the estimating equation for the proportion of the endowment held in alternative assets is

$$
\operatorname{SHARE}_{i t}=\beta_{0}+\beta_{1} \mu_{i t}+\beta_{2} \sigma_{i t}+\gamma_{t}+\delta_{i}+\omega_{i t}
$$

where $S H A R E_{i t}$ is the proportion of the endowment that university $i$ invests in alternative assets in year $t, \gamma_{t}$ and $\delta_{i}$ represent the time and fixed effects, respectively, and $\omega_{i t}$ is a random error.

17 So me schools in our sample reported data for fewer than 7 years, so they had no observations with the requisite 6 lagged values and therefore are not included in the regressions. This accounts for the fact that the number of schools used to estimate the models is less than the number of schools in the analysis sample. 
By controlling for time and entity fixed effects, this model renders unnecessary most of the independent variables included in previous models that rely on cross sectional data. ${ }^{18}$

As it stands, equation (4) does not include variables that vary over time and across universities. In the literature on household investments, the most commonly included such variable is the size of the portfolio (and often its square). However, the inclusion of portfolio size in an equation estimating portfolio composition is problematic because these variables could be jointly determined. Lerner et al. (2008) document a strong relationship between university endowment size and portfolio performance, and note that the causality could run in either direction. ${ }^{19}$ Therefore, our preferred specification leaves out the size of the endowment. Nevertheless, for the sake of comparison with previous studies we estimate a variation of the model that includes a quadratic in endowment size. As shown below, this turns out not to affect our substantive results.

The decision to own alternative assets. It is also of some interest to investigate whether a university holds any alternative assets at all. In the literature on household portfolio allocation, researchers typically address this issue by estimating a model in which the probability that a household owns the risky asset in any given year depends on some set of variables such as education, age and race. (See, for example, Bertaut and Starr-McCluer (2002).) Such a setup implicitly allows the household to switch back and forth between holding and not holding the

18 Note that the inclusion of fixed effects takes into account any unchanging preferences for various perquisites that are not as sociated with augmenting the general quality of the university, a factor that is central to Gilbert and Hrdlicka's (2013) model of university endowment decisions. To allow for the possibility that such preferences might be changing over time, we estimated a variant of the basic model with interactions between the time and university effects. The results were essentially unchanged - the coefficients on $\mu_{i t}$ and $\sigma_{i t}$ are the same up to the third significant digit.

19 The same concerns about the direction of causality apply to many other time-varying characteristics of institutions that might be candidates for right-hand-side variables, like nu mber of students, faculty-student ratios, number of support staff, payout-to-income ratios, and so on. It is equally possible that the size of the endowment "determines" such variables as such variables "determine" the size of the endowment. Indeed, Michael (2005) posits just such a model, estimating regressions with variables such as faculty-student ratios and research expenditures on the left-hand side, and with the size of the endowment as an exploratory variable. 
risky asset. This makes perfect sense in the household context because, as Chapman et al. (2004) show, many households do such switching in response to changes in, for example, stock prices. However, this model may not be well suited for examining the behavior of university endowment managers. As noted earlier, once a university invests in alternative assets, it virtually always does so continually thereafter. Hence, the appropriate question is not how background income affects the probability of investing in alternative assets in a given year, but rather how it affects the probability of making a permanent switch to including alternative assets in its portfolio.

Formally, let the indicator variable $A_{i t}$ equal one if university $i$ owns alternative as sets in period $t$, and zero otherwise. Once a university achieves a value of $A_{i t}=1$, it has reached an absorbing state, and $A_{i t}$ will be 1 in all subsequent periods. A suitable statistical framework is a discrete-time hazard model in which the first period of positive investment in alternative assets for a university represents the end of a duration period. In the jargon of statistics, this transition into the absorbing state is called a "failure." Every period of "survival" - in our context, each year in which a university's endowment portfolio includes no alternative assets - is included in the sample as a university that did not fail. Every university that begins to invest in alternative assets contributes only one failure observation to the sample. Using only observations for which $A_{i, t-1}=0$, the probability that a university $i$ transitions to holding alternative assets in year $t$ is estimated with a logit model. ${ }^{20}$ The right hand side variables include $\mu_{i t}, \sigma_{i t}$, and time effects. Because fixed effects cannot be incorporated into a discrete time hazard model, we also include a vector of university characteristics on the right hand side.

20 For an example of the use of logit to estimate a discrete time hazard model, see Shumway's (2001) study of the determinants of bankruptcy. 
A final econometric issue relates to the computation of standard errors for the estimated coefficients of the share and participation equations. The standard errors should be clustered at the university level to allow for correlation of errors within institutions. However, because $\mu_{i t}$ and $\sigma_{i t}$ are generated by our estimates of the forecasting process of endowment managers, they are estimated with error, so that conventional robust standard errors are not appropriate. We therefore use the method of clustered bootstrapping to generate the standard errors throughout the analysis (Efron and Tibshirani, 1986).

\section{Findings}

\subsection{Basic results.}

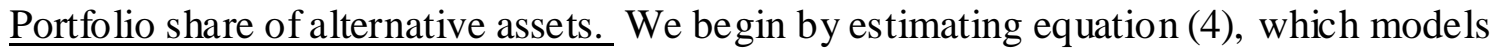
the share of the endowment held in alternative assets. The results are shown in the first column of Table $2 .^{21}$ The positive coefficient on $\mu_{i t}$ implies that a higher level of expected background income is associated with a larger proportion of alternative assets in the university endowment, and the negative coefficient on $\sigma_{i t}$ indicates that higher variability in background income is associated with a smaller proportion. The positive mean-effect and the negative risk-effect are both statistically significant at conventional levels. ${ }^{22}$ To assess the quantitative implications of the results, we follow Dimmock (2012) and use the coefficients on $\mu_{i t}$ and $\sigma_{i t}$ to simulate the effects of one standard deviation increase s in expected background income and background risk,

21 For brevity, the estimated time effects are not reported in Table 2. However, as would be expected from the trends discussed above, the time effects indicate a gradual shift away from relatively safe, low-return investments to alternative assets after the widely observed success of the endowment model. The same result is present in all subsequent regressions as well.

Recall that the results are based on the use of a 6-year window to estimate equation (1). We also experimented with 5 and 7 year windows. For the 5 -year window, the estimated coefficients on $\mu_{i t}$ and $\sigma_{i t}$ were 0.1282 (s.e. $=$ 0.0527 ) and -0.0324 (s.e. $=0.0592$ ), respectively. For the 7 -year window, the corresponding coefficients were 0.1198 (s.e. $=0.0293$ ) and -0.0291 (s.e. $=0.0096)$, respectively. The point estimates are quite similar to the results in Table 2, although the coefficient on $\sigma_{i t}$ using the 5-year window is imp recisely estimated. 
respectively. We find that a one standard deviation increase in expected background income generates a 7.5 percentage point increase in the proportion of the endowment portfolio invested in alternative as sets. A one standard deviation increase in background risk decreases the proportion of the endowment invested in alternative assets by 1.1 percentage points. Are changes of this magnitude important? While importance is in the eye of the beholder, it seems to us that 7.5 and 1.1 percentage point increases from an average of 16.7 percentage points, representing increases of 45 percent and 7 percent, respectively, are big enough to matter.

This approach to assessing the quantitative implications of our results is similar to that used in previous papers (see Dimmock (2012)), and hence is useful for facilitating comparisons. However, a possible drawback is that, given the skewness of the variables, looking at the effects of one standard deviation increases might not be meaningful. As an alternative, we follow Vissing-Jorgensen (2002) and also use our regression coefficients to estimate how the share of the portfolio in alternative assets changes when we move from the $25^{\text {th }}$ to $75^{\text {th }}$ percentiles of the distributions of $\mu_{i t}$ and $\sigma_{i t}$, respectively. We find that the share of a university's portfolio held in alternative assets increases by 4.1 percentage points and decreases by 0.3 percentage points with such increases in expected background income and background risk, respectively. These figures tell essentially the same story as the computations based on one-standard deviation increases in $\mu_{i t}$ and $\sigma_{i t}$.

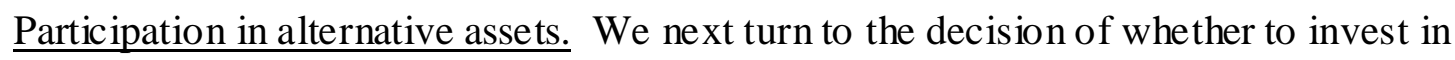
alternative assets at all. As indicated above, we estimate a discrete-time hazard model to examine how changes in expected background income and background risk affect the probability that a university invests in alternative assets. The marginal effects implied by the logit coefficients are presented in the second column of Table 2 . The results are again consistent with the notion that 
increases in expected background income increase the demand for alternative assets and increases in background risk decrease it. The coefficients imply that a one standard deviation increase in expected background income increases the probability of transitioning to alternative assets by 11.3 percentage points, and a one standard deviation increase in background risk decreases the likelihood of making an initial investment in alternative assets by 8.2 percentage points. As above, we also examined the implications of our results for changes in the values of $\mu_{i t}$ and $\sigma_{i t}$ from the $25^{\text {th }}$ to $75^{\text {th }}$ percentile. We find that the like lihood that a university decides to include alternative assets in its portfolio in a given year increases by 6.2 percentage points with such an increase in expected background income, and decreases by 2.4 percentage points with a similar increase in background risk.

In the hazard model, there is effectively only one observation for each university, which rules out the inclusion of fixed effects to take into account characteristics of universities that might affect their portfolio decisions. We therefore augment the model with a set of indicator variables for whether the school is public or private, and for the most advanced degree the school offers. These variables, which are plausibly exogenous, have been shown to affect university economic decisions in other contexts (Brown et al., 2010). An interesting result in this regard is that the indicator for public universities is negative and statistically significant; that is, other things being the same, public universities are less likely than private universities to start investing in alternative assets in any given year.

In summary, whether we look at the portfolio share of alternative assets or at the decision whether or not to invest in alternative assets, the results with respect to the role of background income are the same. Both sets of estimates support the conclusion of a positive mean effect and a negative variability effect on endowment managers' demand for alternative assets. These 
results are consistent with the models of Merton (1992) and others who argue that when flows of income into a university become riskier, endowment managers take steps to reduce the riskiness of their portfolio. Conversely, while these findings do not directly contradict other models that posit goals such as endowment hoarding or return maximization, they do not offer any support for such models either.

\subsection{Alternative specifications}

Including endowment size. Studies of household portfolio behavior typically include financial wealth and perhaps its square as explanatory variables. ${ }^{23}$ The analog for a university, the size of the endowment, varies both across universities and over time, and hence is not taken into account by the inclusion of fixed effects. We did not include endowment size in our basic model because of concerns that it might be jointly determined with portfolio composition. Still, given that it is commonplace to include the size of portfolio, it seems worthwhile to see whether doing so has any effect on our substantive findings.

Table 3 presents the results when our basic models are augmented with a quadratic in the size of the endowment. Neither endowment size nor its square has a significant impact on the proportion of wealth invested in alternative assets or the decision to undertake investments in them. ${ }^{24}$ Furthermore, the coefficients of primary interest, which measure the effects of $\mu_{i t}$ and $\sigma_{i t}$ on share and participation decisions, retain the same signs and are still significant in the augmented models, although in absolute value they are somewhat smaller. Hence, although our preference is to exclude endowment size to avoid potential endogeneity bias, even if we follow the conventional approach of including it, our substantive results do not change.

23 See, for example, the papers in the volume by Guiso et al. (2002).

24 Further, a test of the joint hypothes is that the coefficients on endowment size and its square are zero yields a pvalue of 0.375 for the share equation and 0.694 for the participation equation, indicating that they are not jointly significant. 
Allowing behavior to vary by type of institution. It has been documented that different types of universities vary in their financial behavior (Lowry, 2004). The distinction between public and private institutions is salient in this respect (Carnesale, 2006). Endowment activities are generally more transparent at public universities, since taxpayer dollars are at stake (Gordon et al., 2002). This substantial risk of public embarrassment may make endowment managers at public schools more averse to portfolio risk. Also, Dimmock (2012) notes that endowment boards at private universities average twice as many members as their public counterparts. A greater chance of agency problems arises from a larger and more complex governance structure, as any given endowment manager may be less concerned with hedging background risk. Finally, Martin (2002) reports that public institutions have historically been more dependent on external support than private institutions. With less control over their own finances, public universities may be particularly sensitive to fluctuations in background income.

It therefore is of some interest to explore the possibility that the impact of background income on portfolio allocation decisions varies between public and private universities. We also examine whether there are differences in this respect between research and non-research institutions, ${ }^{25}$ and between universities that have relatively large endowments (above the median) and relatively small ones (below the median). Our focus is solely on the share of the endowment devoted to alternative assets (equation (4)). We are not able to estimate discrete-time hazard models for making transitions to holding alternative assets because the various subsamples do not have enough observations to obtain reliable estimates.

Table 4 shows the results when we estimate the share equation (4) for the various subgroups. In order to facilitate comparisons across different types of institutions, we divide the

25 We define research universities as those that spend more than one percent of their background incomes on research funding. This figure was chosen to yield roughly the same number of research and non-research universities. 
regression coefficients on $\mu_{i t}$ by the standard deviations of $\mu_{i t}$ in the respective subgroups, and report these normalized values. We normalize the regression coefficients on $\sigma_{i t}$ in the same way. Thus, the figures in the table represent the change in the proportion of the endowment allocated to alternative as sets that results from a one standard deviation increase in either expected background income or background risk.

Consider first the left panel of Table 4, which displays the results when we estimate the share equation separately for public and private institutions. Higher expected background income leads to a larger share of alternative assets for both types of institution. The magnitude of the effect is larger for public universities. A one standard deviation increase in expected background income raises the share in alternative assets by over 13 percentage points for public universities but only 4 percentage points for private universities. ${ }^{26}$ The point estimates on $\sigma_{i t}$ are negative for both public and private universities, although statistically significant only for public universities. The point estimate for public universities implies that a one standard deviation increase in $\sigma_{i t}$ decreases investment in alternative assets by 2 percentage points; for a private university, the decrease is only about a third of that amount. ${ }^{27}$ The fact that public university endowment managers are more sensitive to uncertainty in background income is consistent with the notion discussed above, that differences in endowment governance structure tend to make public sector endowment managers more conservative than their private sector counterparts. In any case, it appears that our results with respect to the impact of background risk for the overall sample are driven primarily by public institutions.

26 The differences between the coefficients on $\mu_{i t}$ are statistically significant at conventional levels, as are the differences between the coefficients on $\sigma_{i t}$. The same holds true for the differences we find below in the comparisons between research and non-research institutions, and between large-endowment and smallendowment institutions.

27 To help put these figures in perspective, note that in our analysis sample, conditional on having alternative assets, the portfolio share for private universities is 20 percent; for public universities, it is 17.5 percent. 
Previous research has indicated that an institution's research orientation affects the riskiness of its endowment, ${ }^{28}$ so we next examine whether institutions that grant $\mathrm{PhDs}$ and those that do not differ in how they respond to changes in $\mu_{i t}$ and $\sigma_{i t} \cdot{ }^{29}$ The results when we estimate our basic share equation for the two groups are presented in the middle panel of Table 4 . For both types of schools, the signs on $\mu_{i t}$ and $\sigma_{i t}$ are the same as in the basic model. The coefficients for institutions that do not grant $\mathrm{PhDs}$ are statistically significant, and suggest that a one standard deviation increase in expected background income increases the share of alternative assets by about 4.4 percentage points, and an analogous increase in background risk decreases the share by 1.2 percentage points. The coefficients for doctoral institutions are very close in signs and magnitudes to those of non-doctoral institutions, but they are imprecisely estimated, perhaps due to the smaller number of available observations.

Finally, we divide the sample based on the size of the endowment, estimating the baseline equation separately for schools whose endowments are above and below the median value (approximately $\$ 90$ million in 2009 dollars). ${ }^{30}$ In doing so we recognize that, as mentioned earlier, the magnitude of the endowment could very well be endogenous and stratifying on an endogenous variable can lead to inconsistent parameter estimates. The results, presented in the right panel of Table 4, indicate that endowment managers' alternative asset allocations are more sensitive to background risk for large than for small endowments. While the coefficients on

28 Dimmock (2012) includes research-to-income ratio as an independent variable in his analysis of endowment responses to background risk, arguing that research spending serves as a proxy for university cost structure and for university type, both of which may have an impact on portfolio choice. He finds research spending to be a statis tically significant determinant of overall portfolio risk.

29 As an alternative, we classified an institution as being a research university if it spent more than one percent of its background income on research funding. The results are similar to those presented below.

30 The number of observations for each subpopulation is not the same, as schools with larger endowments tend to have submitted more years of data to NACUBO. The corre lation between the nu mber of years of NACUBO data available for a university and the size of its endowment is +0.25 . This correlation could reflect a variety of considerations, including the fact that universities with relatively s mall endowments might not care enough about endowment polic ies at other institutions to submit their information to NACUBO. 
$\mu_{i t}$ and $\sigma_{i t}$ for both groups have the expected signs, only the coefficients for large-endowment schools are significant, and the magnitudes of the effects of a one-standard deviation increase in either variable are two to three times greater for large than for small endowments. A largeendowment school would show a 5.8 percentage point increase and a 2.0 percentage point decrease in the share of alternative assets in response to one standard deviation increase s in expected background income and background risk, respectively.

These findings are consistent with the fact that large endowments are more likely than small endowments to have active, professional management. This is because, as Brown et al. (2011) observe, the development of financial expertise is a fixed cost that "can be justified only if it can be spread across a sufficiently large asset base." We conjecture that such sophisticated managers are more likely to update their decisions each year based on new data regarding background income streams than the managers of endowments that follow more passive, or even mechanical strategies. ${ }^{31}$

Volatility of the endowment. We have focused on endowment managers' choices regarding alternative assets, both because this has been the topic in much of the literature and it is a prominent issue in popular discussions about university finances. One could argue, though, that at least during certain time periods, some alternative assets might be less volatile than "conventional" investments like publicly traded stocks, and therefore concentrating on alternative assets could be inappropriate. To deal with this issue, we examine the impact of background risk on the overall volatility of the endowment. To begin, we estimate an autoregression of the logarithm of the real value of the endowment on its lagged value, and use

31 The fact that the size of the endowment is not statistically significant in Table 3 while our estimates of the coefficients on $\mu_{i t}$ and $\sigma_{i t}$ differ between high-endowment and low-endowment institutions suggests that the size of the endowment has no effect on the level of the proportion of the portfolio allocated to alternative assets, ceteris paribus. Rather, the effect operates through interactions with $\mu_{i t}$ and $\sigma_{i t}$. 
the estimated parameters to compute the expected value of the endowment (conditional on the lagged value) and its volatility. In the second stage, we estimate a regression of the portfolio's volatility on the expected value of background income and its standard deviation (our $\mu_{i t}$ and $\sigma_{i t}$ variables as above), as well as university and year effects. The key result is that the endowment's volatility increases with the expected value of background income and decreases with the uncertainty of background income, ceteris paribus, and both coefficients are statistically significant. $^{32}$ In short, like our findings relating to portfolio allocations for alternative assets, the evidence is consistent with the notion that endowment managers take both the level and riskiness of background income into account when making their decisions.

\section{Conclusions}

What functions do university endowments serve? This question has been controversial for a long time, and interest in it has intensified in recent years as more and more endowments have invested in the relatively risky and illiquid assets collectively known as alternative assets. In this context, two related questions are salient. First, when endowment managers make their portfolio allocation decisions, do they think only in terms of the assets that they manage, or do they also take into account background income, the other flows of income into the university? Second, if they do take background income into account, do endowment managers hedge against its risks? That is, if they perceive that background income is becoming more risky, do they reduce the exposure of the endowment to risky as sets? Although some theoretical models suggest that endowment managers behave in this fashion, others indicate that, depending on the form of their objective function, this need not be the case.

32 Specifically, the coefficient on $\mu_{i t}$ is $0.0505(\mathrm{~s} . \mathrm{e} .=0.0195)$ and the coefficient on $\sigma_{i t}$ is $-0.0150(\mathrm{~s} . \mathrm{e} .=0.00705)$. 
To investigate these issues, we have analyzed panel data on 729 universities' portfolio decisions over the period 1987-2009. Our findings support the prediction that university endowment managers are more likely to invest in alternative assets, and invest in them more heavily, when expected university background income increases and when its variability declines.

While we cannot rule out other views of the goals of university endowment managers, our results suggest that one important function of university endowments is to hedge against revenue shocks. Thus, universities with low expected levels of background income or more variable streams of such income seek less risk in their financial investments. At the same time, such institutions are also more likely to confront circumstances that require them to use some of the endowment principal to maintain daily operations, increasing the importance of liquidity in their portfolios. For both reasons, then, their endowment managers will tend to shy away from alternative assets, which are the riskiest and the most illiquid of all the asset clas ses.

A number of issues remain to be explored. First, the role of higher-order moments of background income merits consideration. Portfolio decisions might depend not only on the mean and standard deviation of background income, but also on the probability of an extreme event, such as a devastating shock to (say) state government grants income during a recession. Another possible topic is suggested by the fact that while the investments that comprise the alternative asset category can generally be characterized as illiquid and risky, in some respects they are fairly heterogeneous. An investment in a hedge fund is different from an investment in a stand of timber. It would be useful to examine in more detail the interactions among the demands for the various categories within alternative assets, and in particular, if they respond differently to changes in background income. 


\section{References}

Agarwal, V. and Naik, N. (2004). Risk and Portfolio Decisions Involving Hedge Funds. Review of Financial Studies, 17(1), 63-98.

Arrondel, L., Pardo H.C., and Oliver X. (2010). Temperance in Stock Market Participation: Evidence from France. Economica, 77(306), 314-333.

Bertaut, C. C. and Starr-McCluer, M. (2002). Household Portfolios in the United States. In Guiso, Luigi, Michael Haliassos and Tullio Jappelli (eds.), Household Portfolios. Cambrid ge, MA: MIT Press.

Black, F. (1976). The Investment Policy Spectrum: Individuals, Endowment Funds and Pension Funds. Financial Analysts Journal, 32(1), 23-31.

Brown, J., Dimmock, S., Kang, J., and Weisbenner, S. (2014). How University Endowments Respond to Financial Market Shocks: Evidence and Implications. American Economic Review, 104(3), 931-962.

Brown, J., Dimmock, S., Kang, J., Richard son, D., and Weisbenner, S. (2011). The Governance of University Endowments: Insights from a TIAA-CREF Institute Survey. TIAA-CREF Institute Research Dialogue, 102.

Brown, K.C., Garlappi, L., and Tiu, C. (2010). Asset Allocation and Portfolio Performance: Evidence from University Endowment Funds. Journal of Financial Markets, 13(2), 268-294.

Brown, S., Goetzmann, W., Liang, B., and Schwarz, C. (2008). Mandatory Disclosure and Operational Risk: Evidence from Hedge Fund Registration. Journal of Finance, 63(6), 2785 2815.

Carnesale, A. (2006). The Private-Public Gap in Higher Education. The Chronicle of Higher Education, 15(18), B20.

Cejneck, G., Franz, R., Randl, O., and Stoughton, N. (2013). A Survey of University Endowment Management Research. Available at SSRN 2205207.

Chapman, K., Dow, J. P. Jr., and Hariharan, G. (2004). Changes in Stockholding Behavior: Evidence from Household Survey Data. Finance Research Letters, 2(2): 89-96.

Desrochers, D.M. and Wellman, J.V. (2011) Trends in College Spending, 1999-2009, Delta Cost Project, Washington, DC.

Dimmock, S.G. (2012). Background Risk and University Endowment Funds. The Review of Economics and Statistics, 94(3), 789-799. 
Efron, B. and Tibshirani, R. (1986). Bootstrap methods for standard errors, confidence intervals, and other measures of statistical accuracy. Statistical science, 54-75.

Gilbert, Thomas and Hrdlicka, Christopher, 'Why Do University Endowments Invest So Much in Risky Assets?” Working Paper, University of Washington, March 2015.

Goetzmann, W. N., and Oster, S. (2012). Competition among university endowments (No. w18173). National Bureau of Economic Research.

Gollier, C. and Pratt, J.W. (1996). Risk Vulnerability and the Tempering Effect of Background Risk. Econometrica, 64(5), 1109-1123.

Gordon, T., Fischer, M., Malone, D., and Tower, G. (2002). A Comparative Empirical Examination of Extent of Disclosure by Private and Public Colleges and Universities in the United States. Journal of Accounting and Public Policy, 21(3), 235-275.

Guiso, L., Haliassos, M., and Jappelli, T. (2002). Household Portfolios. Cambridge, MA: MIT Press.

Guiso, L., Jappelli, T., and Terlizzese, D. (1996). Income Risk, Borrowing Constraints, and Portfolio Choice. The American Economic Review, 86(1), 158-172.

Hansmann, H. (1990). Why Do Universities Have Endowments? Journal of Legal Studies, 19, 3.

Heaton, J. and Lucas, D. (2000). Portfolio Choice in the Presence of Background Risk. Economic Journal, 110(460), 1-26.

Humphreys, J., Electris, C., Fapohunda, Y., Filosa, J., Goldstein, J., Grace, K. (2010). Educational Endowments and the Financial Crisis: Social Costs and Systemic Risks in the Shadow Banking System. Center for Social Philanthropy, Tellus Institute.

Kaplan, S.N. and Schoar, A. (2005). Private Equity Performance: Returns, Persistence, and Capital Flows. Journal of Finance, 60(4), 1791-823.

Kimball, M.S. (1993). Standard Risk Aversion. Econometrica, 61(3), 589-611.

Lau, Y. and Rosen, H.S. (2014). Are Universities Becoming More Unequal? Working Paper, Princeton University.

Lerner, J., Schoar, A., and Wang, J. (2008). Secrets of the Academy: The Drivers of University Endowment Success. Journal of Economic Perspectives 22(3): 207-22.

Lowry, R.C. (2004). Markets, Governance, and University Priorities: Evidence on Undergraduate Education and Research. Economics of Governance, 5, 29-51. 
Major Private Gifts to Higher Education. Chronicle.com. The Chronicle of Higher Education, 20 October 2013.

Martin, Robert E. (2002). Why Tuition Costs Are Rising So Quickly. Challenge, 45(4), 88-108.

Merton, Robert (1971). Optimum Consumption and Portfolio Rules in a Continuous-time Model. Journal of Economic Theory, 3(4), 373-413.

Merton, Robert (1992). Optimal Investment Strategies for University Endowment Funds. In Studies of Supply and Demand in Higher Education, edited by C. Clotfelter and M. Rothschild. Chicago: University of Chicago Press.

Michael, Steve O. (2005). The Cost of Excellence: The Financial Implications of Institutional Rankings. International Journal of Educational Management, 19(5), 365-382.

Morse, Robert. Rise in Endowments May Impact Best Colleges' Rankings. USNews.com. US News \& World Report, 9 February 2012.

Shumway, Tyler (2001). Forecasting Bankruptcy More Accurately: A Simple Hazard Model. The Journal of Business, 74(1), 101-124.

Stewart, James (2013). How Cooper Union's Endowment Failed in Its Mission. The New York Times 10 May 2013, Business sec. Web.

Swensen, David F. (2009). Pioneering Portfolio Management: An Unconventional Approach to Institutional Investment. New York, NY. Print.

Tobin, James (1974). What is Permanent Endowment Income? American Economic Review, 64(2), 427-432.

Vissing-Jorgensen, A. (2002). Towards an Explanation of Household Portfolio Choice Heterogeneity: Nonfinancial Income and Participation Cost Structures. National Bureau of Economic Research, Working Paper No. 8884. 
Table 1*

\section{Summary Statistics}

\section{Proportion}

Public

$29.1 \%$

Doctoral

$31.0 \%$

Master's

$28.9 \%$

Bachelor - Liberal Arts

$23.3 \%$

Bachelor - General

$8.6 \%$

\begin{tabular}{|c|c|c|c|c|c|}
\hline Background Income & Mean & Std Dev & $25^{\text {th }}$ percentile & Median & $75^{\text {th }}$ percentile \\
\hline $\begin{array}{l}\text { Background Income (\$ millions) } \\
\text { Tuition Revenues } \dagger \\
\text { Public Funding } \dagger \\
\text { Private Giving } \dagger\end{array}$ & $\begin{array}{r}358.71 \\
119.97 \\
217.49 \\
34.12\end{array}$ & $\begin{array}{c}580.21 \\
137.59 \\
381.47 \\
70.36\end{array}$ & $\begin{array}{c}57.06 \\
40.64 \\
4.96 \\
6.05\end{array}$ & $\begin{array}{l}111.46 \\
69.59 \\
26.38 \\
13.31\end{array}$ & $\begin{array}{c}380.31 \\
145.33 \\
277.09 \\
31.86\end{array}$ \\
\hline Endowment Funds & Mean & Std Dev & $25^{\text {th }}$ percentile & Median & $75^{\text {th }}$ percentile \\
\hline $\begin{array}{l}\text { Endowment Size (\$ millions) } \\
\text { Asset Allocation }(\%) \\
\text { Alternative Assets } \\
\text { Equities } \\
\text { Fixed Income } \\
\text { Cash }\end{array}$ & $\begin{array}{c}16.7 \\
58.9 \\
20.9 \\
3.4\end{array}$ & $\begin{array}{c}1,600.0 \\
\\
17.3 \\
13.5 \\
9.8 \\
4.9\end{array}$ & $\begin{array}{c}76.22 \\
\\
2.0 \\
51.5 \\
14.5 \\
0.3\end{array}$ & $\begin{array}{c}179.21 \\
11.4 \\
60.4 \\
20.2 \\
1.9\end{array}$ & $\begin{array}{c}471.64 \\
\\
25.8 \\
68.0 \\
26.4 \\
4.7\end{array}$ \\
\hline
\end{tabular}

* The first panel shows the distribution of universities in the sample by institution type and the four largest categories of degree type. The calculations in this panel are not weighted, i.e., they do not depend on the number of observations for each university in the analysis sample. The second panel shows financial information obtained from the IPEDS dataset, computed over all observations in the analys is sample. The third panel reports data obtained from the NACUBO data set about the endowment portfolios of the universities computed across all observations in the analysis sample. All dollar figures are in millions of 2009 dollars; the adjustment is made using the CPI.

$\dagger$ Some observations are missing data for the categories of background income. We take summary statistics only over the observations for which we have data, which is why the sum of the means of these components does not equal the mean of total background income. 
Table 2*

\section{Allocation to and Participation in Alternative Assets}

\begin{tabular}{lcc}
\hline & Share Equation & Participation Equation \\
\hline$\mu_{i t}$ & $0.1284 * * *$ & $0.1929 * * *$ \\
$\sigma_{i t}$ & $(0.03823)$ & $(0.0595)$ \\
Public & $-0.03328^{* *}$ & $-0.2480^{* *}$ \\
& $(0.01402)$ & $(0.1200)$ \\
Doctoral & & $-0.0911 * *$ \\
& & $(0.0384)$ \\
Masters & & -0.0088 \\
& & $(0.0498)$ \\
Constant & & -0.0377 \\
& -0.00912 & $(0.0360)$ \\
Observations & $(0.01 .214)$ & \\
Number of schools & & \\
University fixed effects? & 4,549 & 206 \\
Time effects? & 566 & No \\
\hline
\end{tabular}

*This table shows the estimates of the baseline model of endow ment investment in alternative assets. $\mu_{i t}$ is the university's forecast of background income based on the estimated parameters of equation (2). $\sigma_{i t}$ is the variability of background income over a 6 year period, computed using equation (3). Both are expressed in units of $\$ 1$ billion. The first column has estimates of equation (4), the share equation. The left hand side variable is the proportion of the endowment invested in alternative assets, expressed as a number between 0 and 1 . The second column shows the marginal effects on the probability of making a transition from not having any alternative assets to having alternative assets implied by a discrete time hazard model. The partic ipation equation is estimated only over observations that involved a transition from not owning to owning alternative assets. A number of schools in our sample were invested in alternatives since the first year of data in our sample, which is why the number of schools in the second column is less than the number in the first column. Bootstrapped standard errors are in parentheses. Significance levels are indicated by: $* 10 \%, * * 5 \%, * * * 1 \%$ level. 
Table 3*

Including Endowment Size as a Control

\begin{tabular}{lcc}
\hline & Share Equation & Participation Equation \\
\hline$\mu_{i t}$ & $0.09426^{* * *}$ & $0.1520^{* *}$ \\
$\sigma_{i t}$ & $(0.03603)$ & $(0.0716)$ \\
Endowment size & $-0.02642^{* *}$ & $-0.2054^{* *}$ \\
& $(0.01303)$ & $(0.1047)$ \\
(Endowment size $)^{2}$ & 0.04869 & 0.0608 \\
& $(0.05215)$ & $(0.1585)$ \\
Public & $-9.61 \mathrm{e}-13$ & $-2.00 \mathrm{e}-12$ \\
& $(4.40 \mathrm{e}-12)$ & $(9.74 \mathrm{e}-11)$ \\
Doctoral & & $-0.0838^{* *}$ \\
& & $(0.0419)$ \\
Masters & & -0.0106 \\
& & $(0.0443)$ \\
Constant & & -0.0331 \\
& & $(0.0407)$ \\
Observations & -0.00686 & \\
Number of schools & $(0.01257)$ & \\
University fixed effects? & & \\
Time effects? & 4,542 & Yes \\
\hline
\end{tabular}

*This table shows the effects of augmenting the basic model with a quadratic in the value of the endowment. $\mu_{i t}$ is the university's forecast of background income based on the estimated parameters of equation (2). $\sigma_{i t}$ is the variability of background income over a 6 year period, computed using equation (3).Both are expressed in units of $\$ 1$ billion. The first column has estimates of equation (4), the share equation. The left hand side variable is the proportion of the endowment invested in alternative assets, expressed as a number between 0 and 1 . The second column shows the marginal effects on the probability of making a transition from not having any alternative assets to having alternative assets implied by a discrete time hazard model. Bootstrapped standard errors are in parentheses. A number of schools in our sample were invested in alternatives since the first year of data in our sample, which is why the number of schools in the second column is less than the number in the first column. Significance levels are indicated by: $* 10 \%, * * 5 \%, * * * 1 \%$ level. 


\section{Table 4*}

Endowment Share of Alte rnative Assets by Subgroups

\begin{tabular}{|c|c|c|c|c|c|c|}
\hline & $\begin{array}{c}\text { Private } \\
\text { Universities }\end{array}$ & $\begin{array}{c}\text { Public } \\
\text { Universities }\end{array}$ & $\begin{array}{c}\text { Doctoral } \\
\text { Universities }\end{array}$ & $\begin{array}{c}\text { Non-Doctoral } \\
\text { Universities } \\
\end{array}$ & $\begin{array}{c}\text { Large } \\
\text { Endowments }\end{array}$ & $\begin{array}{c}\text { Small } \\
\text { Endowments } \\
\end{array}$ \\
\hline$\mu_{i t}$ & $\begin{array}{l}0.04036 * * \\
(0.01847)\end{array}$ & $\begin{array}{l}0.1321 * * * \\
(0.04861)\end{array}$ & $\begin{array}{c}0.04782 \\
(0.04479)\end{array}$ & $\begin{array}{c}0.04379 * * * \\
(0.01686)\end{array}$ & $\begin{array}{l}0.05764 * * \\
(0.02655)\end{array}$ & $\begin{array}{c}0.02088 \\
(0.02119)\end{array}$ \\
\hline$\sigma_{i t}$ & $\begin{array}{l}-0.00627 \\
(0.00529)\end{array}$ & $\begin{array}{c}-0.01910 * * \\
(0.00913)\end{array}$ & $\begin{array}{l}-0.00986 \\
(0.01439)\end{array}$ & $\begin{array}{c}-0.01178^{* *} \\
(0.00488)\end{array}$ & $\begin{array}{c}-0.02023 * * \\
(0.00884)\end{array}$ & $\begin{array}{l}-0.00936 \\
(0.00574)\end{array}$ \\
\hline Constant & $\begin{array}{l}0.02561 * * \\
(0.01105)\end{array}$ & $\begin{array}{c}-0.1025 * * * \\
(0.03356)\end{array}$ & $\begin{array}{l}-0.00050 \\
(0.03440)\end{array}$ & $\begin{array}{l}-0.00291 \\
(0.01301)\end{array}$ & $\begin{array}{c}0.00663 \\
(0.01604)\end{array}$ & $\begin{array}{c}0.00698 \\
(0.01685)\end{array}$ \\
\hline $\begin{array}{l}\text { Observations } \\
\text { \# of universities }\end{array}$ & $\begin{array}{c}3,313 \\
407\end{array}$ & $\begin{array}{c}1,235 \\
162\end{array}$ & $\begin{array}{c}1,583 \\
169\end{array}$ & $\begin{array}{c}2,957 \\
401\end{array}$ & $\begin{array}{c}2,574 \\
287\end{array}$ & $\begin{array}{c}1,072 \\
237\end{array}$ \\
\hline
\end{tabular}

* This table shows the results when the portfolio allocation model (equation (4)) is estimated separately for various university types. The leftmost panel compares private and public universities, the middle panel compares research and non-research universities, and the rightmost panel compares schools with relatively large (above the median) endowments and small endowments. The left hand side variable is the proportion of the endowment invested in alternative assets, expressed as a number between 0 and 1 . The expected value $\left(\mu_{i t}\right)$ and standard deviation $\left(\sigma_{i t}\right)$ of background income are calculated using the income process model detailed in equations (1), (2), and (3), which are estimated separately for each subgroup of universities. To facilitate comparisons across types of institutions, the coefficients of $\mu_{i t}$ and $\sigma_{i t}$ are divided by the standard deviations of $\mu_{i t}$ and $\sigma_{i t}$, respectively, calculated separately for each subgroup. Bootstrapped standard errors are in parentheses. Significance levels are indicated by: $* 10 \%, * * 5 \%, * * * 1 \%$ level. 